\title{
Feeding pregnant and lactating mice Rhodiola kirilowii extracts helps to preserve thymus function of their adult progeny
}

\author{
K. Bieńn ${ }^{1}$, S. Lewicki ${ }^{1}$, R. Zdanowski ${ }^{1}$, \\ E. Skopinska-Różewska ${ }^{2,3}$, M. Krzyżowska ${ }^{1}$ \\ ${ }^{1}$ Department of Regenerative Medicine, Military Institute of Hygiene and Epidemiology, \\ Kozielska 4, 01-163 Warsaw, Poland \\ ${ }^{2}$ Department of Pathomorphology, Biostructure Center, Medical University, \\ Chałubińskiego 5, 02-004 Warsaw, Poland \\ ${ }^{3}$ Department of Microwave Safety, Military Institute of Hygiene and Epidemiology, \\ Kozielska 4, 01-163 Warsaw, Poland
}

\begin{abstract}
Plants belonging to Rhodiola kirilowii species, members of Rhodiola genus and Crassulaceae family, grow wildly in Tibet, Mongolia and China mountains and are traditionally used as adaptogens, antidepressants and anti-inflammatory remedies. Nowadays, $R$. kirilowii is cultivated in some countries, also in Poland. In our previous papers we reported immuno- and angio-modulatory effects of aqueous and hydro-alcoholic extracts of radix and rhizome of this plant in non-pregnant and pregnant mice. The aim of the present study was to evaluate the effect of feeding pregnant and further lactating mice these extracts on selected thymus function parameters in adult progeny. The counts of M-30+ apoptotic cells, in the thymuses obtained from progeny of mice fed during pregnancy and lactation water or $50 \%$ water-alcoholic extract of Rhodiola kirilowii, were significantly lower $(\mathrm{p}<0.05)$ than apoptotic cells counts observed in the control mice. No significant differences in the counts of IL-7-positive cells in the thymuses obtained from progeny of the control mice and mothers treated with water or hydro-alcohol extracts of Rhodiola kirilowii were observed.
\end{abstract}

Key words: mice, pregnancy, Rhodiola kirilowii, progeny, thymus, apoptosis, IL-7

\section{Introduction}

Herbal remedies with immunotropic activity provide an alternative or complementation to conventional therapy of infections during pregnancy. However, some of these remedies may show a negative influence on fetal organ development and function, because they contain various potentially antiangiogenic substances (Skopińska-Różewska et al. 2008 a,b,c, Zdanowski et al. 2012). The aim of the present study was to evaluate the effect of feeding pregnant and further lactating mice extracts of Rhodiola

Correspondence to: S. Lewicki, e-mail: lewickis@gmail.com 
kirilowii, plant with immunostimulatory properties (Wójcik et al. 2009a), on selected parameters of thymus function in their adult progeny.

The thymus supports production of self-tolerant T-cells with competent and regulatory functions, and their migration to the peripheral blood circulation. The thymus also contains other cells such as thymic epithelial cells (TEC) and dendritic cells, and reciprocal interactions between these cells and thymocytes play essential roles in thymic physiology. During thymocyte and TEC differentiation multiple cellular events occur, such as cell proliferation, survival and apoptosis. In order for a thymocyte to differentiate into a mature $\mathrm{T}$ lymphocyte it must go through several maturational stages.

The thymus is divided into two main regions, the peripheral cortex and a central medulla. Most T-cell development takes place in the cortex, only mature single-positive thymocytes are observed in the medulla. After successful rearrangements of $\alpha$-chains and expression of T-cell receptor in the cortex, $\alpha: \beta$ thymocytes undergo further development determined by interactions of their T-cell receptors with self-peptides presented by the MHC molecules on the thymic stroma. CD4-CD8 double positive thymocytes, whose receptors interact with self-peptide: self-MHC complexes, are positively selected, and will mature into CD4 or CD8 single positive cells. $\mathrm{T}$ cells that react too strongly with self-antigens are deleted in the thymus through the negative selection, which takes place in the medullary region of the thymus. All thymocytes which do not pass through positive or negative selection undergo apoptosis (Godfrey et al. 1993, Nishino et al. 2006).

Interleukin 7 is a $25 \mathrm{kDa}$ glycoprotein produced by stromal cells in the thymus and bone marrow. IL-7 promotes both survival and differentiation of immature double negative, and mature single positive thymocytes. In the periphery, IL-7 regulates T cell survival and function. IL-7 binds the IL-7 receptor (IL-7R) which is expressed on many immune system cells including double negative thymocytes CD4-/CD8-, double positive thymocytes CD4+CD8+ and single positive CD4 or CD8 T cells (Morrissey et al. 1994, von Freeden-Jeffry et al. 1997).

\section{Materials and Methods}

\section{Preparation and chemical analysis of Rhodiola extracts}

The roots and rhizomes of Rhodiola kirilowii were collected from field cultivations of the Institute of Natural Fibers and Medicinal Plants (Poznań, Poland). The raw material was washed, cut into thick slices, dried in natural conditions and next powdered. Aqueous extracts: finely powdered roots were extracted two times with water (extraction was performed: first -2 hour and second -1 hour long, in the ratio raw material/solvent $1 / 5$ ), in the temperature of $40-45^{\circ} \mathrm{C}$. The supernatants were mixed together and after centrifugation at $3000 \mathrm{rpm}$ for $15 \mathrm{~min}$ were lyophilized.

Hydroalcoholic extracts: finely powdered roots were extracted with ethanol/water solution $(1 / 1, \mathrm{v} / \mathrm{v}$, in the ratio raw material/solvent $1 / 10$ ) by the percolation method. Then the percolates were lyophilized (preceded by the distilling off the ethanol in the temperature $40-45^{\circ} \mathrm{C}$ ). Extracts were stored at $-70^{\circ} \mathrm{C}$ until further use.

Chemical analysis of extracts was done as previously described (Lewicki et al. 2015). Total extract polyphenols/flavonoids concentration (16.16 $\mu \mathrm{g} / \mathrm{mg}$ and $23.75 \mu \mathrm{g} / \mathrm{mg}$ in RKW and RKW-A, respectively) was assayed by applying the HPLC system (Dionex) equipped in the CoulArray electrochemical detector (ESA Inc.)

\section{Biological studies}

Experiments were performed in adult 15 female mice of BALB/c strain and in their offspring. For this purpose, females, from the contact with males of the same strain, up to the $28^{\text {th }}$ day after giving birth, were fed daily with aqueous (RKW group) or $50 \%$ hydro-alcoholic (RKW-A group) extracts of $R$. kirilowii (lyophilizates dissolved in distilled water), using the daily dose of $20 \mathrm{mg} / \mathrm{kg}$ of b.m., which was pre-selected as immunostimulatory during previous experiments. The control group received distilled water. The substances were applied on a corn crisp and served to the female in a petri dish. Three-four weeks after birth, the offspring were weaned and divided into groups according to sex (males and females separately). At six weeks of age, 15 pups were weighed and sacrificed. Thymuses from 9 females and 6 males, each from different mother, were collected and weighed. For morphological evaluation, thymuses were fixed in the $4 \%$ paraformaldehyde in PBS for 24h. $6 \mathrm{fm}$ thick tissue slides, previously prepared with the standard histochemical paraffin method, were stained with hematoxylin- eosin.

All experiments were accepted and conducted according to ethical guidance of the Local Bioethical Committee (permission 73/2011). Mice were maintained under conventional conditions (room temperature $22.5-23.0^{\circ} \mathrm{C}$, relative humidity $50-70 \%, 12 \mathrm{~h}$ day/night cycle) with free access to breeding rodent feed (Labofeed H, Wytwórnia Pasz „Morawski”) and water. 
(A)

Apoptotic cells/1000 cells

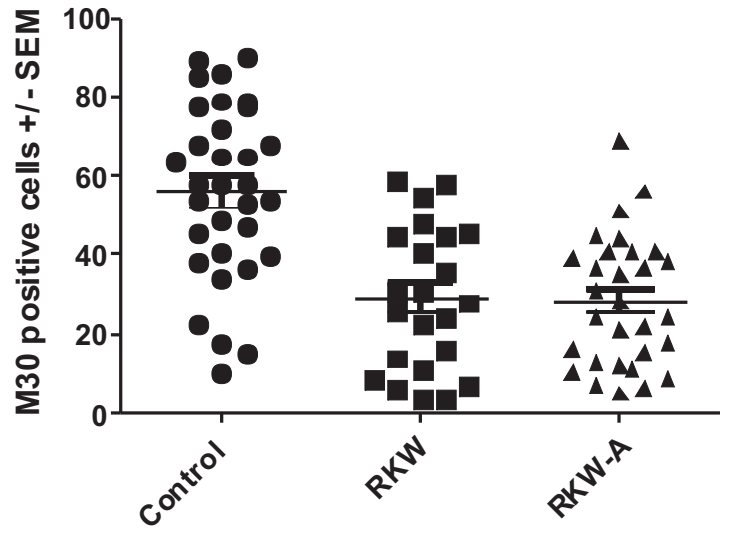

\begin{tabular}{|c|l|}
\hline One-way analysis of variance & \\
\hline $\mathrm{P}$ value & $<0.0001$ \\
\hline $\mathrm{P}$ value summary & ${ }^{* *}$ \\
\hline Are means signif. different? $(\mathrm{P}<0.05)$ & Yes \\
\hline Number of groups & 3 \\
\hline
\end{tabular}

(B)
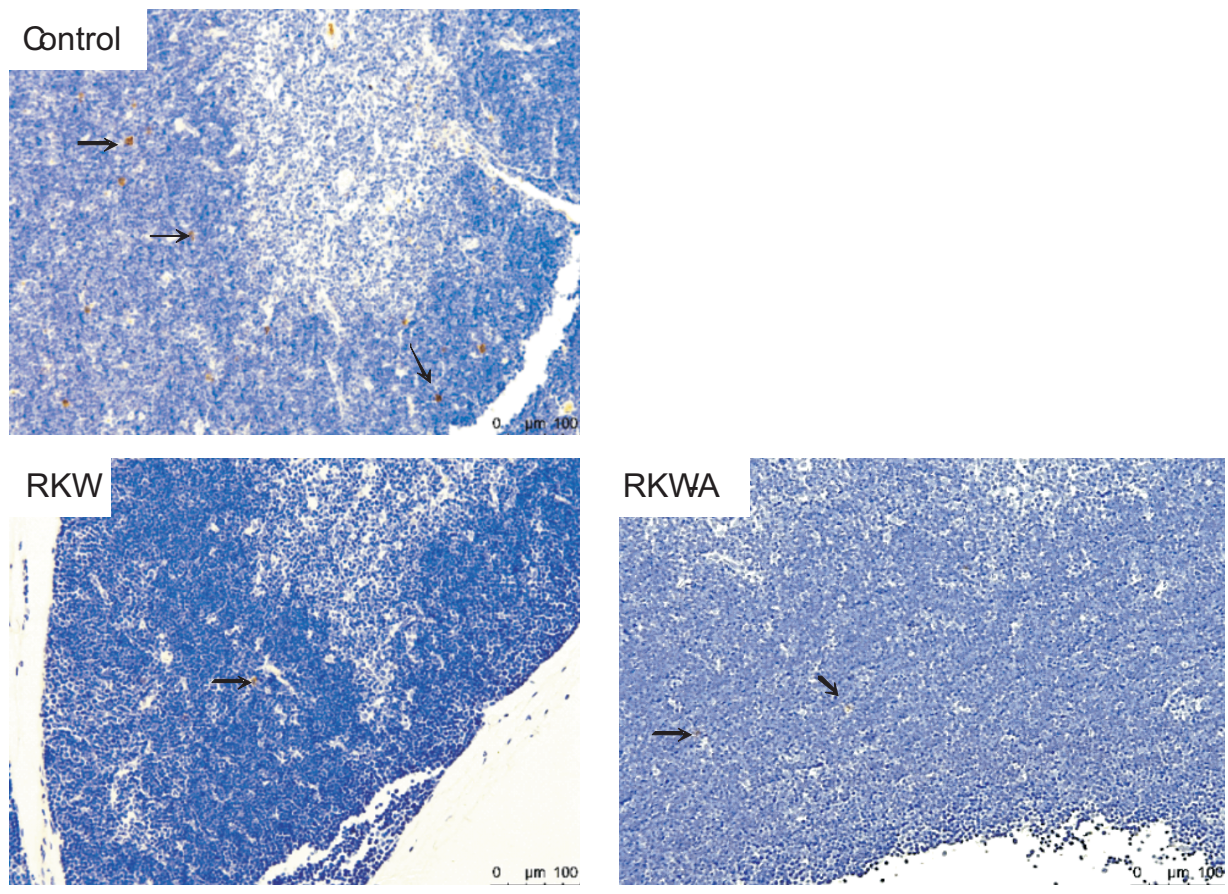

Fig. 1. Apoptotic cell counts (M30-positive)/1000 cells (A) and typical photos of paraffin embedded slides (B) of thymuses isolated from progeny of mothers fed water (RKW) or alcohol extract (RKW-A) from Rhodiola kirilowii. The nuclei in the slides were counterstained with Harris haematoxylin (violet). $\rightarrow-$ examples of apoptotic cells (M30-positive, brown color). 4400.

\section{Immunohistochemical stainings}

M30- and IL-7-positive cells were detected by immunohistochemical staining. Briefly, thymuses were removed, fixed in $4 \%$ paraformaldehyde in PBS for $24 \mathrm{~h}$, then dehydrated and embedded in paraffin and cut into $6-\mu \mathrm{m}$ sections on a microtome. The sections were further subjected to antigen retrieval in $0.1 \mathrm{M}$ citrate buffer ( $\mathrm{pH}$ 6.0) for $10 \mathrm{~min}$. M30 and IL-7 antigens were detected with M30 CytoDEATH kit (Roche, Indianapolis, IN, USA) and rabbit anti-IL-7 antibody (Abcam, Cambridge, Great Britain) using EnVision + System-HRP (Dako) according to producer's protocol. Briefly, after 30 minutes of incubation with primary antibody diluted in $0.05 \mathrm{~mol} / \mathrm{L}$ Tris- $\mathrm{HCl}$ buffer, $\mathrm{pH} 7.2,1 \%$ bovine serum albumin at 
(A)

\section{IL-7 positive cells/1000 cells}

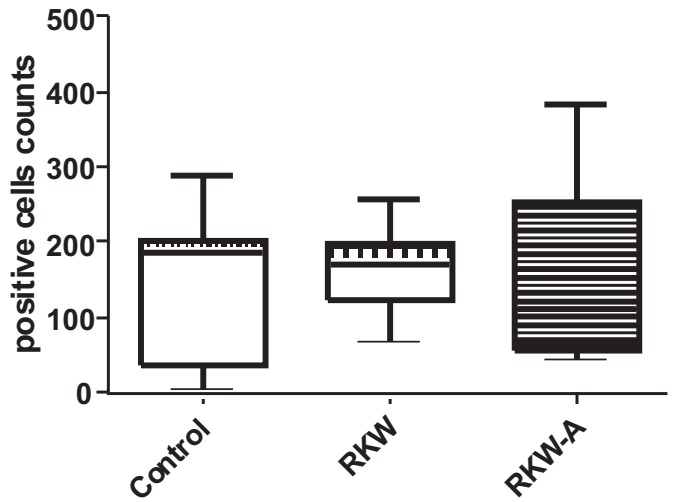

\begin{tabular}{|c|l|}
\hline Kruskal-Wallis test & \\
\hline $\mathrm{P}$ value & 0.6803 \\
\hline Exact or approximate $P$ value? & Gaussian Approximation \\
\hline $\mathrm{P}$ value summary & ns \\
\hline Do the medians vary signif. $(\mathrm{P}<0.05)$ & No \\
\hline
\end{tabular}

(B)
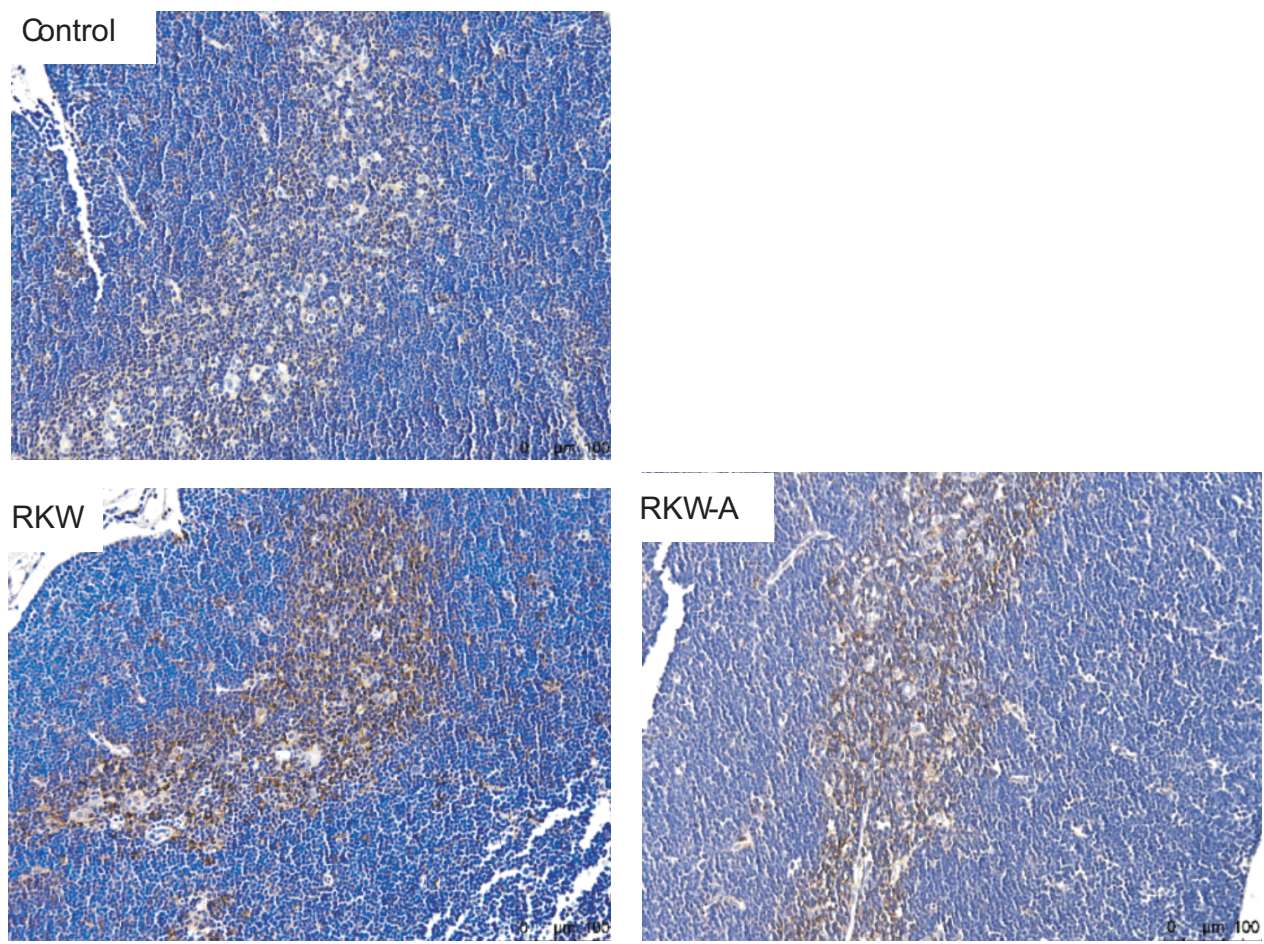

Fig. 2. Interleukin-7 positive cells/1000 cells (A) and typical photos of paraffin embedded slides (B) of thymuses isolated from progeny of mothers fed water (RKW) or alcohol extract (RKW-A) from Rhodiola kirilowii. Brown color - IL-7-positive cells. The nuclei in the slides were counterstained with Harris haematoxylin (violet). $\mathrm{x} 400$.

room temperature, peroxidase labeled polymer conjugated was added for another 15 minutes. Sections were developed with 3,3'-diaminobenzidine (DAB) and counterstained with Harris's hematoxylin solution (Sigma Aldrich). The stained sections were dehydrated in graded series of ethanol followed by xylene and mounted with DPX (Sigma Aldrich). The images were captured with camera-equipped Zeiss Axio Imager.M1 microscope using ZEN 2 software. Numbers of IL-7-positive and M30-positive cells per each thymus section were counted on 10 slides. The results are showed as counts per 1000 cells. 


\section{Statistical analysis}

Statistical evaluation of the results obtained in the control and experimental groups was done using one-way ANOVA with Tukey post-test (in the case of apoptotic cells) and with non-parametric Kruskal-Wallis test for IL-7 positive cells (GraphPad Software Inc. San Diego, USA).

\section{Results}

\section{Histomorphological study}

In the control group the thymus structure had specific features, common in mice. Numerous lobules were separated with connective tissue septums and had the cortex and the medulla. In the cortex, lymphocytes and lymphoblasts are predominant. In the medulla, groups of large clear epithelial cells were observal. The vessels of the medulla were plethoric.

In the experimental groups no changes as compared with the control were observed. The lobular structure, and the ratio of the cortex and the medulla did not differ from those found in the control. The content of the epithelial cells was the same. No hyperplasia or atrophy of the thymus were detected.

\section{Immunohistochemical study}

Apoptotic cells (M30-positive cells) were observed mainly in the cortex of the thymus, albeit single apoptotic cells were also observed in the medulla. The counts of apoptotic cells in the thymuses of mice which mothers were treated with water (RKW) or hydro-alcoholic (RKW-A) extracts of Rhodiola kirilowii were significantly lower $(\mathrm{p} \leq 0.05)$ than apoptotic cells counts observed in the control mice (Fig. 1).

Staining for IL-7 revealed positive cells as stromal cells of both the cortex and medulla. No significant differences for the counts of IL-7-positive cells in the thymus between the control progeny and those derived from mothers treated with water or alcohol extracts of Rhodiola kirilowii were observed (Fig. 2).

\section{Discussion}

In recent years, our studies have shown that extracts from plants belonging to Rhodiola species can enhance various in vitro and in vivo parameters of cellular immunity in mice, rats and pigs, which has become a goal for research (Furmanowa et al. 1998, Siwicki et al. 2007, 2012, Skopińska-Różewska et al. 2008d,e, 2009, 2010, 2011, 2012, Wójcik et al. 2008, 2009a,b,c, Bany et al. 2009, Hartwich 2010, Zdanowski et al. 2014, Lewicki et al. 2015).

A study by Liu et al. (2015) showed that Rhodiola rosea alcoholic extract markedly decreased the apoptotic rate of thymus lymphocytes in 9 week old $\mathrm{BALB} / \mathrm{c}$ mice. The authors used Rhodiola rosea extract to treat $\mathrm{BALB} / \mathrm{c}$ mice with induced sepsis. The study revealed that compared to the sepsis group the expression of pro-apoptotic proteins, Fas and FasL in the treatment group was significantly decreased, while the expression of anti-apoptotic Bcl-2 was increased. This indicates that extracts of Rhodiola may exert a positive effect, by protecting from infection- or age-induced decrease in functioning of the thymus.

In order for a thymocyte to differentiate into a mature $\mathrm{T}$ lymphocyte it must go through maturational stages. The first stage is termed the double-negative (DN) stage because thymocytes in this stage lack the CD4 or CD8 co-receptors. Double-negative thymocytes go through several stages ending with successful $\beta$ selection (expression of a functional TCR $\beta$ chain and a pre-TCR $\alpha$ chain on the cell surface). After successful $\beta$ selection, double-negative thymocytes must be able to respond to cytokines released from thymic stromal cells in order to survive and transit to the double-positive stage (Godfrey et al. 1993, Nishino et al. 2006). IL-7 and the ligand for CD117, stem cell factor (SCF) are crucial for the survival of double-negative thymocytes (Morrissey et al. 1994, von Freeden-Jeffrey et al. 1997).

IL-7 receptor (IL-7R) is expressed on DN thymocytes. IL-7R signalling regulates $B$ cell lymphoma 2 (Bcl-2) family members. The Bcl-2 family is composed of pro-apoptotic (Bim, Bax, Bak, Bik, Puma, Noxa, Bad, etc.) and anti-apoptotic (Bcl-2, Bcl-xL, Bcl2-A1, Bcl-w, Mcl-1) proteins (Youle and Strasser 2008). A balance of the Bcl-2 family members is crucial in maintaining cell survival. Dysregulation of the balance between anti- and proapoptotic proteins may lead to apoptosis induction (excess of pro-apoptotic proteins) or apoptosis suppression (up-regulation of anti-apoptotic proteins). The link between IL-7 signalling and the ratio in expression of individual $\mathrm{Bcl}-2$ family members that promotes survival of DN cells was shown (Peschon et al. 1994, Khaled et al. 1999). Loss of IL-7R signalling in DN cells caused translocation of pro-apoptotic Bax to mitochondria, leading to apoptotic cell death. Therefore, a balance in expression of the Bcl-2 family members via IL-7R signalling allows the double-negative population to go to the further developmental stages.

After TCR $\alpha$ chain rearrangement, thymocytes transit to the double-positive (DP) stage. Thè TCR selection' leads to a fate similarly dependent on the 
balance of pro- and anti-apoptotic members of the Bcl-2 family. Binding avidity between self-peptide MHC and a thymocyte TCR determines the outcome of selection, where peptides with low-affinity and relatively rare expression lead to positive selection and the inhibition of apoptosis, while stronger signals through the TCR result in negative selection (Godfrey et al. 1993, Nishino et al. 2006). Thymocytes, which do not go through positive or negative selection, undergo apoptosis. The signalling mechanisms that are responsible for the balance of pro- and anti-apoptotic proteins during DP stage are still under research, albeit much attention is focused on the role of mitogen-activated protein kinases (MAPKs) and their intracellular pathways (Daniels et al. 2006).

In rodents, the development of the thymus is not finished until 4-5 weeks of age. Aging of the mouse thymus starts from 12 weeks of age (Sempowski et al. 2002). The mice used in this study were 6 week old, which means that their thymuses were fully developed.

Here, we found that progeny of mice treated with Rhodiola kirilowii extracts showed significantly lower total counts of apoptotic cells and that such treatment of mothers had no significant influence upon IL-7 expression on progeny thymocytes. We can therefore conclude that Rhodiola kirilowii extracts help to preserve thymus function in progeny of the treated animals, which may be of relevance upon challenge with infection.

\section{Acknowledgements}

The study was supported by National Centre of Science, grant number: 2012/05/B/NZ 7/03219.

\section{References}

Bany J, Zdanowska D, Skopinska-Różewska E, Sommer E, Siwicki AK, Wasiutyński A (2009) The effect of Rhodiola rosea extracts on the bacterial infection in mice. Centr Eur J Immunol 34: 35-37.

Daniels MA, Teixeiro E, Gill J, Hausmann B, Roubaty D, Holmberg K, Werlen G, Hollander GA, Gascoigne NR, Palmer $E$ (2006) Thymic selection threshold defined by compartmentalization of Ras/MAPK signalling. Nature 444: 724-729.

Furmanowa M, Skopińska-Różewska E, Rogala E, Hartwich M (1998) Rhodiola rosea in vitro culture- phytochemical analysis and antioxidant action. Acta Soc Bot Pol 67: 69-73.

Godfrey DI, Kennedy J, Suda T, Zlotnik A (1993) A developmental pathway involving four phenotypically and functionally distinct subsets of CD3-CD4-CD8- triple-negative adult mouse thymocytes defined by CD44 and CD25 expression. J Immunol 150: 4244-4252.
Hartwich M (2010) The importance of immunological studies on Rhodiola rosea in the new effective and safe herbal drug discovery. Centr Eur J Immunol 35: 263-266.

Khaled AR, Kim K, Hofmeister R, Muegge K, Durum SK (1999) Withdrawal of IL-7 induces Bax translocation from cytosol to mitochondria through a rise in intracellular pH. Proc Natl Acad Sci USA 96: 14476-14481.

Lewicki S, Stankiewicz W, Skopinska-Różewska E, Wilczak J, Leśniak M, Suska M, Siwicki AK, Skopiński P, Zdanowski R (2015) Spleen content of selected polyphenols, splenocytes morphology and function in mice fed Rhodiola kirilowii extracts during pregnancy and lactation. Pol J Vet Sci 18: 847-855.

Liu MW, Su MX, Zhang W, Zhang LM, Wang YH, Qian CY (2015) Rhodiola rosea suppresses thymus T-lymphocyte apoptosis by downregulating tumor necrosis factor- $\alpha$-induced protein 8 -like- 2 in septic rats. Int $\mathbf{J}$ Mol Med 36: 386-398.

Morrissey PJ, McKenna H, Widmer MB, Braddy S, Voice R, Charrier K, Williams DE, Watson JD (1994) Steel factor (c-kit ligand) stimulates the in vitro growth of immature CD3/CD4/CD8 thymocytes: synergy with IL-7. Cell Immunol 157: 118-131.

Nishino M, Ashiku SK, Kocher ON, Thurer RL, Boiselle PM, Hatabu H (2006) The thymus: a comprehensive review. Radiographics 26: 335-348.

Peschon JJ, Morrissey PJ, Grabstein KH, Ramsdell FJ, Maraskovsky E, Gliniak BC, Park LS, Ziegler SF, Williams DE, Ware CB, Meyer JD, Davison BL (1994) Early lymphocyte expansion is severely impaired in interleukin 7 receptor-deficient mice. J Exp Med 180: 1955-1960.

Sempowski GD, Gooding ME, Liao HX, Le PT, Haynes BF (2002) $T$ cell receptor excision circle assessment of thymopoiesis in aging mice. Mol Immunol 38: 841-848.

Siwicki AK, Skopinska-Różewska E, Hartwich M, Wójcik R, Bakuła T, Furmanowa M, Bałan BJ, Sommer E, Mielcarek S, Buchwald W, Krajewska-Patan A, Mścisz A, Mrozikiewicz PM, Bany J (2007) The influence of Rhodiola rosea extracts on non-specific and specific cellular immunity in pigs, rats and mice. Centr Eur J Immunol 32: 84-91.

Siwicki AK, Skopińska-Różewska E, Wasiutyński A, Wójcik R, Zdanowski R, Sommer E, Buchwald W, Furmanowa M, Bakuła T, Stankiewicz W (2012) The effect of Rhodiola kirilowii extracts on pigs blood leukocytes metabolic (RBA) and proliferative (LPS) activity, and on the bacterial infection and blood leukocyte number in mice. Centr Eur J Immunol 37: 145-150.

Skopińska-Różewska E, Wasiutyński A, Sommer E, Mielcarek S , Mścisz A, Krajewska-Patan A, Mazurkiewicz M, Pastewka K (2008a) The influence of Rhodiola rosea, Rhodiola kirilowii, and Rhodiola quadrifida extracts on cutaneous angiogenesis induced in mice after grafting of human kidney cancer tissue. Centr Eur J Immunol 33: $185-189$.

Skopińska-Różewska E， Hartwich M, Siwicki AK, Wasiutyński A, Sommer E, Mazurkiewicz M, Bany J, Skurzak H (2008b) The influence of Rhodiola rosea extracts and rosavin on cutaneous angiogenesis induced in mice after grafting of syngeneic tumor cells. Centr Eur J Immunol 33: 102-107.

Skopińska-Rózewska E, Malinowski M, Wasiutyński A, Sommer E, Furmanowa M, Mazurkiewicz M, Siwicki AK 
(2008c) The influence of Rhodiola quadrifida $50 \%$ hydro-alcoholic extract and salidroside on tumor-induced angiogenesis in mice. Pol J Vet Sci 11: 97-104.

Skopińska-Różewska E, Bychawska M, Sommer E, Siwicki AK (2008d) The in vivo effect of Rhodiola quadrifida extracts on the metabolic activity of blood granulocytes in mice. Centr Eur J Immunol 33: 179-181.

Skopinska-Różewska E, Wójcik R, Siwicki AK, Sommer E, Wasiutyński A, Furmanowa M, Malinowski M, Mazurkiewicz M (2008e) The effect of Rhodiola quadrifida extracts on cellular immunity in mice and rats. Pol J Vet Sci 11: 105-111.

Skopinska-Różewska E, Bychawska M, Białas-Chromiec B, Sommer E (2009) The in vivo effect of Rhodiola rosea and Rhodiola quadrifida hydro-alcoholic extracts on chemokinetic activity of spleen lymphocytes in mice. Centr Eur J Immunol 34: 42-45.

Skopińska-Różewska E, Bychawska M, Białas-Chromiec B, Sommer E, Furmanowa M, Mrozikiewicz PM, Buchwald W, Mielcarek S, Siwicki AK (2010) The in vivo effect of Rhodiola kirilowii extracts on blood granulocytes metabolic activity in mice. Centr Eur J Immunol 35: 20-24.

Skopińska-Różewska E, Sokolnicka I, Siwicki AK, Stankiewicz W, Dabrowski MP, Buchwald W, Krajewska-Patan A, Mielcarek S, Mścisz A, Furmanowa M (2011) Dose-dependent in vivo effect of Rhodiola and Echinacea on the mitogen-induced lymphocyte proliferation in mice. Pol J Vet Sci 14: 265-272.

Skopińska-Różewska E, Stankiewicz W, Zdanowski R, Siwicki AK, Furmanowa M, Buchwald W, Wasiutyński A (2012) The in vivo effect of Rhodiola quadrifida extracts on the antibody production, blood leukocytes subpopulations and on the bacterial infection in mice. Centr Eur J Immunol 37: 140-144.

von Freeden-Jeffry U, Solvason N, Howard M, Murray $R$ (1997) The earliest $T$ lineage-committed cells depend on IL-7 for Bcl-2 expression and normal cell cycle progression. Immunity 7: 147-154.

Wójcik R, Siwicki AK, Skopinska-Różewska E, Mścisz A, Mielcarek S, Furmanowa M, Mrozikiewicz PM (2008) The in vitro influence of Rhodiola quadrifida extracts on non-specific cellular immunity in pigs. Centr Eur J Immunol 33: 193-196.

Wójcik R, Siwicki AK, Skopińska-Różewska E, Wasiutyński A, Sommer E, Furmanowa M (2009a) The effect of chinese medicinal herb Rhodiola kirilowii extracts on cellular immunity in mice and rats. Pol $\mathrm{J}$ Vet Sci 12: 399-405.

Wójcik R, Siwicki AK, Skopinska-Różewska E, Bakuła T, Furmanowa M (2009b) The in vitro effect of Rhodiola quadrifida and $R$. kirilowii extracts on pigs blood lymphocyte response to mitogen ConA. Centr Eur J Immunol 34: 166-170.

Wójcik R, Siwicki AK, Skopińska-Różewska E, Buchwald W, Furmanowa M (2009c) The in vitro influence of Rhodiola kirilowii extracts on blood granulocytes potential killing activity (PKA) in pigs. Centr Eur J Immunol 34: 158-161.

Youle RJ, Strasser A (2008) The BCL-2 protein family: opposing activities that mediate cell death. Nat Rev Mol Cell Biol 9: 47-59.

Zdanowski R, Lewicki S, Skopińska-Różewska E, Buchwald W, Mrozikiewicz PM, Stankiewicz W (2014) Alcoholand water-based extracts obtained from Rhodiola rosea affect differently the number and metabolic activity of circulating granulocytes in Balb/c mice. Ann Agric Environ Med 21: 120-123.

Zdanowski R, Skopińska-Różewska E, Wasiutyński A, Skopiński P, Siwicki AK, Sobiczewska E, Lewicki S, Buchwald W, Kocik J, Stankiewicz W (2012) The effect of Rhodiola kirilowii extracts on tumor-induced angiogenesis in mice. Centr Eur J Immunol 37: 131-139. 